\title{
Empirical Assessment on Factors Contributing to Integrity Practices of Malaysian Public Sector Officers
}

\section{Razana Juhaida Johari *}

Faculty of Accountancy

Universiti Teknologi MARA

Shah Alam, Malaysia

Email: razana@salam.uitm.edu.my

\section{Md. Mahmudul Alam*}

School of Economics, Finance and Banking

Universiti Utara Malaysia

E-mail: rony000@gmail.com

\author{
Jamaliah Said \\ Accounting Research Institute \\ Universiti Teknologi MARA \\ Shah Alam, Malaysia \\ Email: jamaliah533@salam.uitm.edu.my
}

*Corresponding author

\section{Citation Reference:}

Johari, R.J., Alam, M.M., \& Said, J. (2021). Empirical Assessment on Factors Contribute to Integrity Practices of Malaysian Public Sector Officers. Business Process Management Journal, 27(4), 1217-1237. (Online) https://doi.org/10.1108/BPMJ-06-2020$\underline{0297}$

This is a pre-publication copy.

The published article is copyrighted by the publisher of the journal. 


\title{
Empirical Assessment on Factors Contributing to Integrity Practices of Malaysian Public Sector Officers
}

\begin{abstract}
Purpose - Integrity-related issues are now endemic to public service bureaucracies. It is claimed that corruption in the public sector is very common in various departments/agencies. Lack of integrity will lead to failings in governance and proper oversight of procedures, and subsequently poor financial management and incidents of fraud. Based on the Stakeholder Theory Perspective, this study examines the influences of accountability, risk management and managerial commitment on practices of integrity in the Malaysian public sector. Design/methodology/approach - Primary data were collected through both printed and online questionnaires given to 210 department heads operating within selected Malaysian federal ministries. Data were analysed via the Partial Least Squares-Structural Equation Modelling (PLS-SEM) approach to examine the research hypotheses.

Findings - It is evident that integrity practices in Malaysia's public sector are statistically significantly related to risk management, accountability, and management commitment.

Practical/Policy implications - The findings will help the Malaysian federal ministries to take the necessary steps to improve integrity so that dependability and efficiency are the hallmarks of public sector services.

Originality/value - To the best of the authors' knowledge, this study is one of the first to examine the role of accountability, risk management, and managerial commitment to integrity in the public sector of a developing market economy.
\end{abstract}

Keywords: Public Sector; Integrity; Risk Management; Accountability; Management Commitment.

\section{INTRODUCTION}

Organisational integrity is important to ensure any actions of fraud, pilferage and corruption are minimised and punished so that the public is confident that it is functioning properly. Integrity can be shaped by institutionalisation, the establishment of correct and normal actions in the workplace (Goodstein, 2015). The concept of organisational integrity relates to the levels of ethics and integrity required to improve people's and departments' choices and decisions (Thoms, 2008). By improving integrity, actions of fraud can be greatly reduced or stamped out (Khalid and Said, 2016). Integrity practices describe the characteristics or quality of an individual or organisation's behaviour in line with the standards, rules, and moral values established by its staff and the wider society (Bauman, 2013; Badaracco and Ellsworth, 1991; Engelbrecht, Heine and Mahembe, 2016). These are deemed as greatly influencing organisational actions, decisions, and moral choices directly (TrevinyoRodríguez, 2007), so the organisation's management plays a critical function in developing integrity throughout the workplace (Kaptein, 2003).

In the public sector, integrity practices must ensure public funding is used in a highly efficient and honest manner. The government's main objective is to protect the public interest by having a governance system that is effective and efficient, ensuring that the rights of the public are protected (Aziz et al., 2015). In other words, the system reflects accountability as well as integrity in public sector officers doing their daily tasks properly. In order to protect public resources, integrity practices are crucial to strengthening organisational work culture, transparency, and professionalism (Said \& Omar, 2014; Said, Alam, \& Khalid, 2016). 
Integrity practice is a key element for upholding ethical behaviour among personnel (Brown \& Treviño, 2006; Kaptein, 2011), and minimising fraud as people with a tendency to commit fraud will influence other people in their actions (Dorminey, Fleming, Kranacher, \& Riley, 2012. In contrast, failure to practice integrity may promote mismanagement, misuse of power, and lead to conflicts of interest and fraud (Karim, Said and Bakri, 2015). Some corporate executives are willing to increase profits by engaging in unethical practices (Connor, 2007; Kochan, 2006; Shaxson, 2007). Such practices are part of an "enterprise culture" that persuades many to believe that "bending the rules" for corporate gain is a sign of business acumen (Rosli et al., 2015). This in turn will simply compromise integrity practices in an organisation.

Scholars generally agree that public sector organisations must serve the public as best they can, hence good corporate integrity systems should be adopted to minimise financial mismanagement (Bovens, Goodin, \& Schillemans, 2014; Brennan \& Solomon, 2008). Many governance mechanisms and concepts are being implemented in order to achieve high levels of accountability. The International Federation of Accountants and The Chartered Institute of Public Finance and Accountancy [henceforth referred to as IFAC and CIPFA, respectively], outlined in the International Framework for Good Governance in The Public Sector, several good governance mechanisms to enhance accountability in the public sector including statutory bodies. Those mechanisms include risk management, accountability systems and management commitment (Asaolu, Adedokun, \& Monday, 2016; INTOSAI, 2004; Suyono \& Hariyanto, 2012), human resource management practices (Arulrajah, 2016), leadership (Doh $\&$ Stumpf, 2005) and corporate integrity practices (Aulich, 2011).

Many issues of concern have been surfacing in the Malaysian public sector in recent years in relation to fraud, corruption, failures in governance, weak financial management, and many others. This has given rise to many questions regarding the public sector's level of integrity in upholding public trust. Scandals such as the 1MBD controversy and events at the Royal Malaysian Customs Department (RMCD), have given the public sector a bad reputation as a whole. The scandals supported Ssonko's (2010) findings that the public sector failed to perform its duties with integrity and did not uphold any form of public trust. Generally, the development of corruption and fraud is evident in the statistics for bribery and integrity research and index such as: (i) the integrity survey 2019 conducted by Ernst \& Young (EY); (ii) bribe payers index 2019; and (iii) the survey by Transparency International on Corruption Perception Index 2019. The recent report by EY in 2019 reported that $38 \%$ of respondents in the EY Global Fraud Survey (2018) had observed misconduct in their workplace where the levels of overall misconduct remained virtually unchanged since 2012.

In Malaysia, there have been issues linked to integrity violation issues involving public sector officers. For example misconduct has occurred in Sabah State Water Department (Chan, 2016), Perlis State Water Department (Jamaludin, 2018), Sabah Railway Department (Miwil, 2018), and the Royal Malaysian Navy (RMN) (MACC, 2017a). Malaysian local councils and state offices were also involved in integrity violations, such as Johor Bahru Municipal Council (MACC, 2017b), Kuala Lumpur Municipal Council (Fadzil, 2016), Malacca Stadium Body (BERNAMA, 2016b), and Kelantan State office (Harian, 2017). As such, understanding the motives and reasons for integrity violations makes it possible to propose strategies to mitigate bigger losses in the future (Cressey, 1973; Kolthoff, 2016; Graaf et al., 2017).

Taking into consideration the above facts and arguments as well as what other studies have 
studied, understanding what contributes to integrity practices in the public sector is very important. Employing the Stakeholder Theory (Freeman, 1984; Buysse and Verbeke, 2003) perspective, this study examines the influences of practices of accountability, risk management, and managerial commitment on integrity in the Malaysian public sector. It is hoped that this study will assist the government to identify the factors that nurture and promote the value of integrity in government agencies. The findings can serve to create awareness among policymakers to enforce good governance procedures and integrity among all public sector officers no matter what their rank is.

\section{Integrity Initiatives by Malaysian Public Sector}

Promoting integrity has become an important element of government innovation in most countries. Malaysia is not excluded from this rule and it has renewed its commitment to combat corruption while at the same time promoting good governance to ensure sustained economic growth and fortune. As early as 1967, the Anti-Corruption Agency was set up together with clear instructions to ensure administration was more effective in containing corruption and all kinds of mismanagement in the workplace. Ever since 2003, combating corruption has been firmly part of the government's agenda and new initiatives and strategies have been introduced. Despite devising an anti-corruption framework there is more to be done. Malaysia's civil servants play an important role where their commitment helps to ensure that government policies are implemented correctly (Rusnah et al., 2011).

The Malaysian government is serious in enhancing integrity practices due to corruption in its ministries. However, Malaysia still presents an interesting case where the level of corruption problems are still at a high level while at the same time, most strategies and current campaigns seem to have not made any significant differences in containing or fighting corruption in society (Siddiquee, 2009). For example, in 2013, one case involves Majlis Amanah Rakyat (MARA) having purchased overpriced assets above the market value. In another case in 2007, the National Feedlot Corporation (NFC) was accused of breaching trust of government loan facilities to the amount of RM 49.7 million.

Not surprisingly, Malaysia has been criticised as becoming a very corrupt nation yet at the same time is said to be achieving its targets, especially when economic conditions are tough. This is according to the current survey by Ernst \& Young, which indicates the government's Performance Management and Delivery Unit (Pemandu) failed in ensuring economic growth. Moreover, it was reported by the Asia-Pacific Fraud Survey Report Series 2013 that Malaysia and China have the highest levels of bribery and corruption. The survey involved 681 executives from China, Singapore, Australia, New Zealand, Indonesia, Vietnam, Malaysia and South Korea. Approximately half of the 681 executives involved in the survey expressed their belief that China, Indonesia, Malaysia and Vietnam had the worst levels of bribery and corruption cases.

To fight these corruption practices, the Malaysian government has entrusted the task to the six National Key Result Areas (NKRAs) strategy. Ever since the 1980s, governance of the Malaysian public sector has undergone huge changes as a result of the drive to modernise old practices. In addition, in order to improve ethical issues and to be ranked in the top 30 of the Transparency International's Corruption Perception Index (CPI) by the year 2020, the Malaysian government public service has done its best to deliver services. However, a decline in Malaysia's standing in the Corruption Price Index of Malaysia from 2008 to 2011 confirms that the public does not trust business ethics in Malaysia (Maisarah et al., 2012). A 
number of issues have arisen in the Malaysian public sector on accountability, integrity, and ethics issues (e.g. Alam, Johari and Said, 2018; Amalina, Zunaidah, and Ridzwana, 2014; Johari, Rosnidah, Nasfy, and Sayed Hussin, 2020).

Malaysia is now a successful developing country but struggling to effectively cope with all the weaknesses and problems encountered in becoming a modern nation. The biggest challenge is to strengthen the ethics and integrity framework (National Integrity Plan, 1998) throughout all levels of government. The decline in integrity shown by individuals, organisations as well as the wider society is obvious in the form of corruption, lack of skills, irregularities, misuse of power, deception, other unethical practices and the poor motivation to simply do one's job properly as expected.

\section{LITERATURE REVIEW AND HYPOTHESES DEVELOPMENT}

\section{Risk Management and Integrity}

Risk is an inherent part of business and public life and it covers all aspects of organisational activities including all management levels (Tchankova, 2002). Generally, risk is referred to as the possibility of danger, loss, injury or other adverse consequences (Rasid, Rahman and Ismail, 2011). The risk begins when the business environment is increasingly volatile, uncertain, unstable and unpredictable (Abdullah et al., 2015; Smallman, 1996; Wilson, 2018). Normally, risk is associated with an undesired loss like business collapse, customer trust or loss of market share (Tummala and Achoenherr, 2011). Risk management is a process that is used to identify potential risks and liabilities that could result in problems for both public or private sector organisations (Archbold, 2005). Risk management is an effective way for assessing, detecting and managing the risks that arise. Financial crises and unexpected collapses of many corporations and banks in the United States (US) have resulted in damaging and widespread consequences, including collapsed economic activity, loss of public confidence and unstable financial systems ( $\mathrm{Ng}$ et al., 2013).

$\mathrm{Ng}$ et al. (2013) stated that risks in the organisation may also arise due to the independence of company boards' members. This is because when the members are independent, the problem of conflict of interest may be avoided since their independence will prevent them from having personal interests to follow and this allows them to make fair and objective judgments (Rasid et al., 2011). If company directors could seize corporate opportunities without much restriction like risk management requirements and other internal controls, the company's business integrity is compromised (Ma, 2016). In other words, risk management has a relationship with integrity practice since it can influence and impair integrity as a whole. However, this is in contrast to Said et al. (2016) who found risk management did not wield a statistically significant influence on integrity practices. Thus, a high level of corruption cannot be overcome despite the efforts to combat it. Based on the mixed results from previous research regarding the relationship between risk management and integrity, this study considers the following hypothesis:

H1: There is a significant relationship between risk management and integrity practices in the Malaysian public sector.

\section{Accountability and Integrity}

The term accountability cannot be defined precisely since many researchers have extensively 
debated what it means. In general, accountability is known as the internal and external duty of an individual or organisation to answer for their activities, accept responsibility for them and disclose the results in an honest way which includes the responsibility for money or other entrusted property (Almquist, Grossi, Helden and Reichard, 2013; Aziz et al., 2015; Huse, 2005; Iyoha and Oyerinde, 2010). According to Roberts and Scapens (1985), accountability is defined as a relationship between the giving and demanding of reasons for conduct in any organisation. Accountability is connected to trust and transparency of an individual in reporting workplace duties and it is similar to integrity where it comes to honouring one's word (Chabrak, 2015). There is a connection between accountability and integrity because the latter - when shown by a government department - has a positive impact in nurturing accountability and thus enhancing public sector accountability (Aziz et al., 2015). Jayasinghe and Soobaroyen (2009) stated that in maintaining accountability, the issues of transparency and trust are crucial because without these two concepts of integrity, it is difficult for organisations to maintain any form of trust. Aziz et al. (2015) detected a significant relationship between accountability and integrity. Based on this argument the following hypothesis is developed to explore the relationship:

$\mathrm{H} 2$ : There is a significant relationship between accountability and integrity practices in the Malaysian public sector.

\section{Management Commitment and Integrity}

Management commitment is vital and deemed to be a crucial and desirable element in employees' behaviour (Aladwan, Bhanugopan and Fish, 2013). This is because the success of an organisation can be ensured by senior management commitment. According to Goffin and Szwejczewski (1996) and Millar and Doherty (2016), the major reason for firms failing here is the lack of commitment from top management. According to Goffin and Szwejczewski (1996), management must be willing to exert considerable effort on behalf of the organisation (Mowday et al., 1979; Wombacher and Felfe, 2017; Johari, Alam and Said, 2018) and having a strong desire to maintain its staff. Metcalfe and Dick (2001) noted that workplace commitment significantly influences how employees are managed and how well they do their work.

Since managerial commitment could affect the behaviour of employees, as a leader or manager of a company, what the leader does will be followed by the subordinates, and the same goes with integrity. If the manager is not showing integrity or being ethical in performing his/her job, the employees would do the same thing. Leaders who provide their team with a definite sense of direction and purpose tend to have more satisfied and committed employees. Leroy et al. (2012) found a significant relationship between managers' commitment and behavioural integrity. Hopkin (2012) added that to become a successful manager with a high level of commitment to employees, it is very crucial to build trust with the team they work with and rely on. This is because by developing trust and leading with integrity, it may increase the confidence employees have in their manager or head of department. Therefore, since managerial commitment has a link with managerial integrity, the following hypothesis is developed:

H3: There is a significant relationship between management commitment and integrity practices in the Malaysian public sector. 


\section{UNDERPINNING THEORY \& FRAMEWORK}

Governance underpins all organisations by providing moral obligations and self-binding commitment to comply with the ethical code (Sacconi, 1999; Francés-Gómez, 2003). Public sector organisations have social contracts with the stakeholders and citizens where engagement between society and the business takes place (Gigerenzer \& Hug, 1992). The theory could explain the organisation's fiduciary duties and social responsibilities to owners and all stakeholders and fair distribution of surplus to them (Sacconi, 1999, 2006). The governance of an organisation needs to be effective in order to achieve accountability. Furthermore the framework for this study draws on Stakeholder Theory which was developed by Freeman (1984). This theory explains how the relationship between the organisation and society may affect the integrity system of the public sector (Jensen, 2001). Stakeholders may include all individuals who are affected by the decisions made by the organisation such as employees, customers, communities, government officials and more (Collier, 2008; Jensen, 2001). Figure 1 below shows the stakeholder model to explain the framework that links the relationship among the three variables.

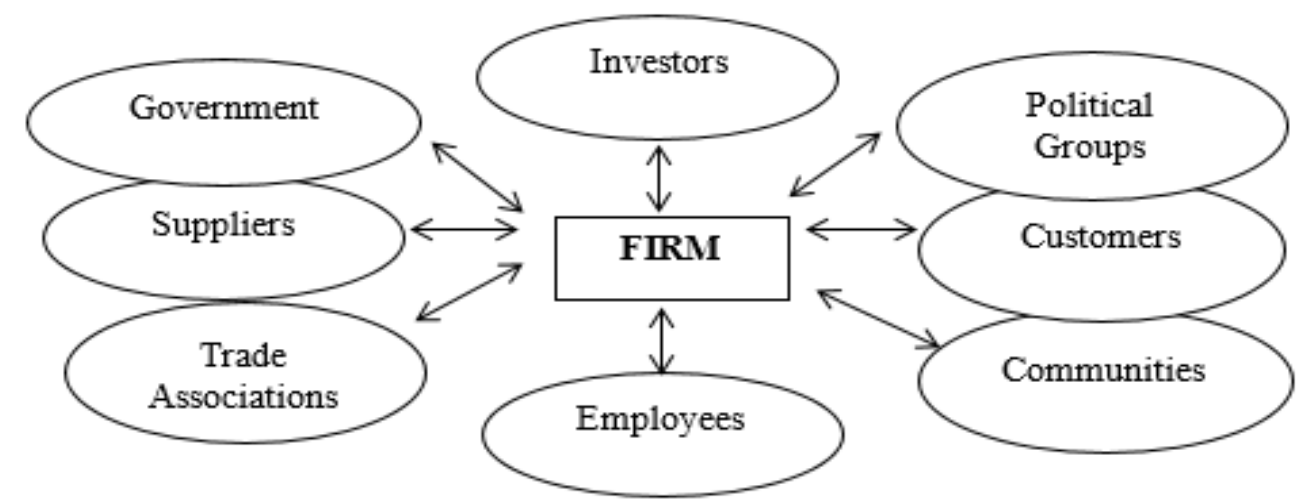

Figure 1: The Stakeholder Model (Freeman, 1984)

In this theory, the first relationship is between integrity and the variable of accountability. Accountability refers to the process where a person or groups of people are held to account for their conduct which includes moral rights and obligations (Dooren, Bouckaert and Halligan, 2015; Glynn and Murphy, 1996). Accountability in the public sector requires the government to answer to the public in order to justify decisions and the use of public resources since the public in a sense 'owns' them (Aziz et al., 2015). Therefore, to ensure all stakeholders are satisfied, management should be able to represent the interests of all stakeholders when making decisions by having more integrity (Collier, 2008; Hall, Blass, Ferris and Massengale, 2004; Kalsi, Kiran and Vaidya, 2009). The same goes for the variable risk management. The management of risks is an integral part of good business practice. Information about the organisation's risk is important not only to shareholders but also to the stakeholders since the latter can use that information for evaluating a company's ability to do business and obey the law. Therefore, proper risk management is likely to help in managing the risks more effectively and in disclosing the risk management outcomes to stakeholders (Subramaniam, McManus and Zhang, 2009). For the variable on the relationship between stakeholders and management commitment, this theory explains how commitment from on organisation's management may affect the loyalty, engagement and attachment of employees.

To ensure that the organisation can identify what the stakeholders believe to be their best 
interests prior to trying to make outcomes materialise (Damak-Ayadi and Pesqueux, 2005; Riege and Lindsay, 2006; Williams and Adams, 2013), each public sector or department needs to identify what the citizens need so that they are satisfied with the actions taken by the department. The crucial aim of the public sector is to safeguard the public interest through an efficient and effective governance system that enhances protection of rights and demonstrates accountability and integrity (Aziz et al., 2015). Therefore, Stakeholder Theory can serve as the framework for this study since it investigates the selected variables that are crucial to integrity practices, i.e. risk management, accountability or management commitment. Finally, the conceptual framework developed shown in Figure 2.

\section{Conceptual Framework}

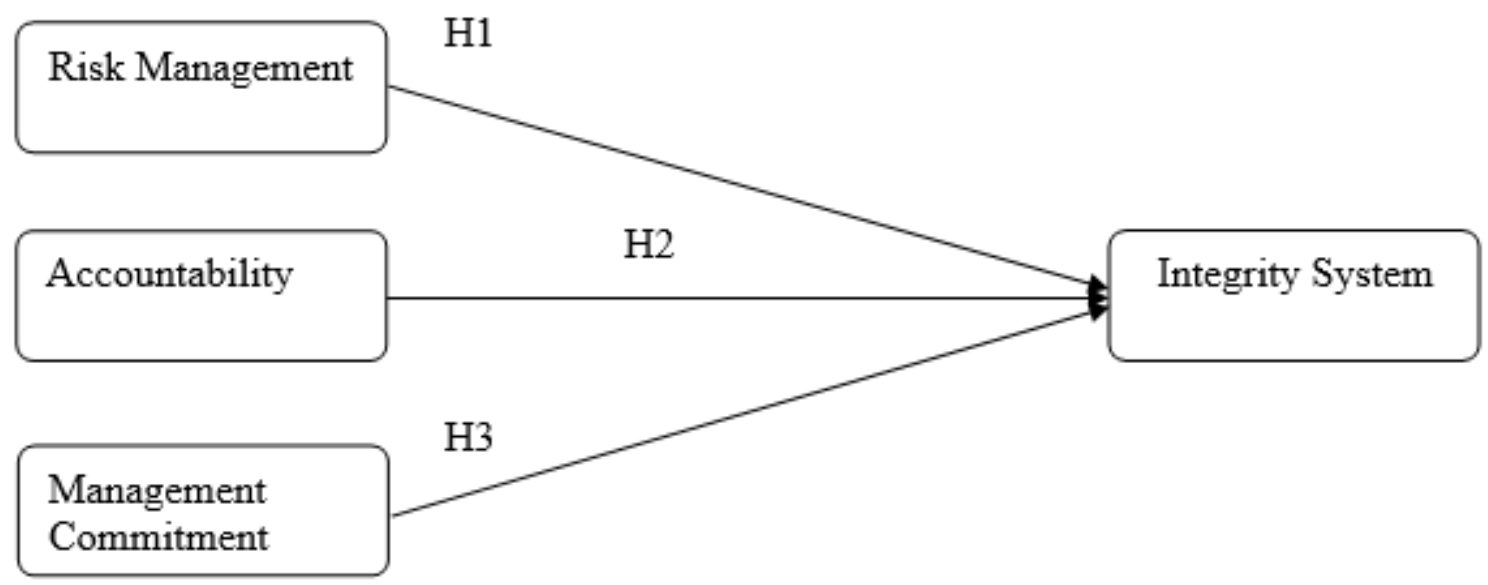

Figure 2: Conceptual Framework

\section{METHODOLOGY}

\section{Sample selection}

The sample for the study consists of six ministries and these are: Ministry of Communication and Multimedia, the Ministry of Education, the Ministry of Health, the Ministry of Defence, the Ministry of Agriculture and Agro-Based Industry, and the Ministry of Rural and Regional Development. These ministries have often been reprimanded in the Report by the Auditor General for three consecutive years from 2012 to 2014 for problems including accountability, integrity, ethics, and mismanagement.

\section{Data collection}

Data collection was carried out by distributing questionnaires to department heads from six Malaysian federal ministries from January to June 2016. These six ministries include a total of 402 sub-departments. A systematic random sampling approach was done by taking two listed departments in every ministry such as the department's second list, fourth list, sixth list, and so on to reach 402. A total of 194 public officers who are the Head of Department (HOD) from each sub-department of federal ministry were selected to represent the department in this study. After distributing 210 questionnaires, 194 questionnaires were returned and used for the data analysis (see Table 1). 
Table 1: List of Sample

\begin{tabular}{cc}
\hline \multicolumn{1}{c}{ Ministry } & No. of sub-departments \\
\hline Ministry of Communications and Multimedia & \\
\hline 1. Department of Broadcasting Malaysia & 13 \\
2. Department of Information Malaysia & 10 \\
\hline Ministry of Education & 10 \\
\hline 3. Johor State Education Department & 10 \\
4. Kelantan State Education Department & 10 \\
5. Labuan Education Department & 10 \\
6. Pahang State Education Department & 10 \\
7. Perak State Education Department & 10 \\
8. Putrajaya Education Department & 10 \\
9. Sabah State Education Department & 10 \\
10. Selangor State Education Department & 6 \\
\hline Ministry of Health & 6 \\
\hline 11. Perlis State Health Department & 6 \\
12. Selangor State Health Department & 6 \\
13. Terengganu State Health Department & 6 \\
14. Sarawak State Health Department & 6 \\
15. Kuala Lumpur State Health Department & 6 \\
16. Perak State Health Department & 6 \\
17. Melaka State Health Department & 13 \\
18. Kedah State Health Department & 12 \\
\hline Ministry of Defence & $\mathbf{2 1 0}$ \\
\hline 19. Department of Veteran Affairs & 15 \\
\hline Ministry of Agriculture and Agro-based Industry & \\
\hline 20. Fishery Department & \\
21. Agriculture Department & \\
\hline Ministry of Rural and Regional Development & \\
\hline 22. Community Development Department & \\
23. Rubber Industry Smallholders Development Authority & \\
\hline Total & \\
\hline
\end{tabular}

\section{ANALYSIS}

\section{Demographic Profiles}

Table 2 shows that $59 \%$ of respondents are female while another $41 \%$ are male. Most of the respondents are in the 31-50 years old age bracket with $33 \%$ being in the 31-40 cohort and $38 \%$ are in the $41-50$ age range.

Table 2: Demographic Information of Respondents

\begin{tabular}{llcc}
\hline & Demographic Profile & $\begin{array}{c}\text { Frequency } \\
(\mathbf{N = 1 9 4 )}\end{array}$ & $\begin{array}{c}\text { Percentage } \\
(\boldsymbol{\%})\end{array}$ \\
\hline Gender: & Male & 79 & 40.7 \\
& Female & 115 & 59.3 \\
\hline Race: & Malay & 176 & 90.7
\end{tabular}




\begin{tabular}{|c|c|c|c|}
\hline & India & 11 & 5.7 \\
\hline & Chinese & 7 & 3.6 \\
\hline \multirow[t]{4}{*}{ Age: } & $20-30$ years & 24 & 12.4 \\
\hline & $31-40$ years & 64 & 33.0 \\
\hline & $41-50$ years & 74 & 38.1 \\
\hline & 51 years and above & 32 & 16.5 \\
\hline Academic & Degree & 100 & 51.5 \\
\hline \multirow[t]{2}{*}{ Qualification: } & Master & 90 & 46.4 \\
\hline & $\mathrm{PhD}$ & 4 & 2.1 \\
\hline \multirow[t]{4}{*}{ Job Position: } & Supporting Staff & 7 & 3.6 \\
\hline & Management and & 176 & 90.7 \\
\hline & Professional & & \\
\hline & Top Management & 11 & 5.7 \\
\hline Department in & Accounting & 45 & 23.2 \\
\hline \multirow{6}{*}{ Organisation: } & Administrative & 78 & 40.2 \\
\hline & Audit & 10 & 5.2 \\
\hline & Education & 2 & 1.0 \\
\hline & Finance & 46 & 23.7 \\
\hline & Information System & 2 & 1.0 \\
\hline & Others & 11 & 5.7 \\
\hline \multirow[t]{4}{*}{ Grade: } & 41 & 51 & 26.5 \\
\hline & 44 & 71 & 36.5 \\
\hline & 48 & 50 & 25.7 \\
\hline & 52 and above & 22 & 11.3 \\
\hline \multirow{4}{*}{$\begin{array}{l}\text { Employment in } \\
\text { Current Organisation } \\
\text { (years): }\end{array}$} & Less than 1 year & 11 & 5.7 \\
\hline & $1-3$ years & 10 & 5.2 \\
\hline & $4-5$ years & 23 & 11.9 \\
\hline & 5 years and above & 150 & 77.3 \\
\hline \multirow{4}{*}{$\begin{array}{l}\text { Employment in the } \\
\text { Public Sector (years): }\end{array}$} & Less than 1 year & 16 & 8.2 \\
\hline & $1-3$ years & 31 & 16.0 \\
\hline & $4-5$ years & 17 & 8.8 \\
\hline & 5 years and above & 130 & 67.0 \\
\hline
\end{tabular}

The majority (905) of respondents are Malays and all respondents possessed a Bachelor's degree; $90.7 \%$ of the respondents hold management positions. As much as $40 \%$ work in the administrative sector while $23.7 \%$ are in the financial services and only $5.2 \%$ are in the accounting sector. The remaining $7.7 \%$ work in other departments as officers in the legal, tax, education, health, procurement, or information and technology departments. A majority of $36.5 \%$ of participants belong to Grade 44 , Grade 48 has $25.7 \%$ and Grade 41 has $26.5 \%$. The statistics also found that $77 \%$ of participants have worked for more than 5 years at the present organisation and $67 \%$ served as public sector officers for more than 5 years.

\section{Measurements}

Based on the consistency and validation of the measurement items that have been utilised in past studies, this study has adapted a 12-item measurement borrowed from Geer (2009) and Shaoul, Stafford and Stapleton (2012) to measure accountability. The measurement items for risk management (12 items) were adapted from Mancuso (2012), while management commitment (10 items) was adapted from Geer (2009), Gollmar and Hopkins (2008) and O'Neil and Williams (2007). Finally, the Corporate Integrity Assessment Questionnaire 
(CIAQ) used to measure the integrity was adapted from the Malaysian Integrity System (2012). All the measurement items were measured with a five-point Likert-type rating scale ranging from 1 (strongly disagree) to 5 (strongly agree) (see Appendix for items).

\section{Data Treatment}

To check data normality, we applied skewness and kurtosis test and found data are not normally distributed. However, according to Field (2013), if the samples amount to more than 30 , it can be considered normal distribution. Common method variance (CMV) is an issue for single source data in social sciences research (Podsakoff et al., 2003). To confirm CMV is not problematic for this data, we employed single factor analysis in SPSS. Results show single factor explains only $37.26 \%$ which is lower than 50\%. According to Podsakoff and Organ (1986), no CMV is present in the data.

\section{Measurement Model}

According to Hair et al. (2014), in Smart-PLS, a two-step procedure should be followed. In the first step the measurement model consists of construct validity and reliability and discriminant validity. In the second step, bootstrapping procedure serves to understand the predictability of independent variables on dependent variables. To validate the measurement model, indicator loading of the items should be more than 0.70 but in some cases 0.50 is acceptable (Hair et al., 2014; Nunnally, 1978; Pallant, 2007). Besides, Cronbach's alpha, composite reliability and average variance extracted (AVE) should be more than $0.70,0.70$ and 0.50, respectively (Hair et al., 2014, 2019; Nunnally, 1978; Pallant, 2007).

Table 3: Construct Validity and Reliability

\begin{tabular}{lccccc}
\hline & Items & Loadings & $\begin{array}{c}\text { Cronbach's } \\
\text { Alpha }\end{array}$ & $\begin{array}{c}\text { Composite } \\
\text { Reliability }\end{array}$ & $\begin{array}{c}\text { Variance } \\
\text { Extracted } \\
\text { (AVE) }\end{array}$ \\
\hline Accountability & AC11 & 0.638 & 0.869 & 0.895 & 0.500 \\
& AC2 & 0.598 & & & \\
& AC3 & 0.565 & & & \\
& AC4 & 0.779 & & & \\
AC5 & 0.861 & & & \\
Antegrity & AC6 & 0.569 & & & \\
system & AC7 & 0.813 & & & \\
& AC8 & 0.719 & & & \\
AC9 & 0.707 & & & \\
& CIS1 & 0.826 & 0.926 & & \\
& CIS10 & 0.683 & & & \\
CIS11 & 0.697 & & & \\
CIS12 & 0.607 & & & \\
CIS13 & 0.772 & & & \\
CIS2 & 0.703 & & & \\
CIS4 & 0.755 & & & \\
& & & & & \\
& & & & \\
\end{tabular}




\begin{tabular}{|c|c|c|c|c|c|}
\hline & $\begin{array}{l}\text { CIS5 } \\
\text { CIS6 } \\
\text { CIS7 } \\
\text { CIS9 } \\
\end{array}$ & $\begin{array}{l}0.841 \\
0.855 \\
0.730 \\
0.848 \\
\end{array}$ & & & \\
\hline \multirow[t]{2}{*}{$\begin{array}{l}\text { Management } \\
\text { commitment }\end{array}$} & $\mathrm{MC} 1$ & 0.733 & 0.894 & 0.916 & 0.554 \\
\hline & $\begin{array}{c}\text { MC10 } \\
\text { MC2 } \\
\text { MC3 } \\
\text { MC4 } \\
\text { MC5 } \\
\text { MC6 } \\
\text { MC7 } \\
\text { MC8 }\end{array}$ & $\begin{array}{l}0.652 \\
0.746 \\
0.854 \\
0.733 \\
0.475 \\
0.873 \\
0.889 \\
0.655\end{array}$ & & & \\
\hline \multirow[t]{2}{*}{$\begin{array}{l}\text { Risk } \\
\text { management }\end{array}$} & RM11 & 0.715 & 0.908 & 0.924 & 0.551 \\
\hline & $\begin{array}{l}\text { RM12 } \\
\text { RM2 } \\
\text { RM3 } \\
\text { RM4 } \\
\text { RM5 } \\
\text { RM6 } \\
\text { RM7 } \\
\text { RM8 } \\
\text { RM1 }\end{array}$ & $\begin{array}{l}0.773 \\
0.816 \\
0.562 \\
0.860 \\
0.713 \\
0.659 \\
0.742 \\
0.708 \\
0.828\end{array}$ & & & \\
\hline
\end{tabular}

To meet all the criteria for the measurement model, three items from accountability were deleted to increase AVE to 0.50, while two items each from risk management, management control and integrity system were discarded due to poor loading below 0.50 . Consequently, all the measurements have a modest reliability since they exceed the recommended value of the fit measurement model (Hair et al., 2019; Nunnally, 1978; Pallant, 2007).

Table 4: Variance Inflation (VIF)

\begin{tabular}{lcccc}
\hline & 1 & 2 & 3 & VIF \\
\hline 1. Accountability & & & & 1.957 \\
2. Integrity system & 0.739 & & & \\
3. Management commitment & 0.758 & 0.789 & & 3.066 \\
4. Risk management & 0.714 & 0.791 & 0.862 & 2.873 \\
\hline
\end{tabular}




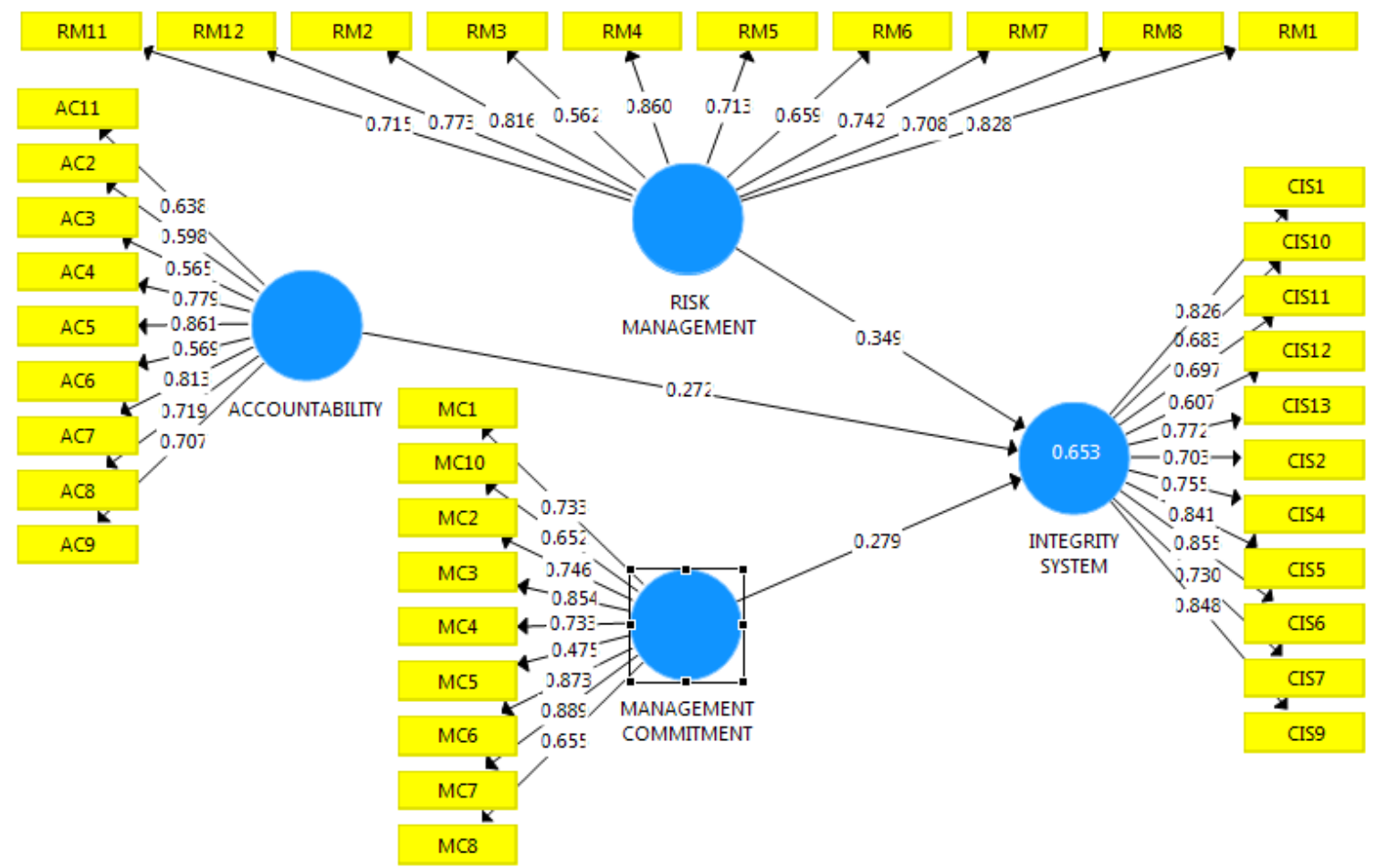

Figure 3: Measurement Model with Indicator Loading

Furthermore, high multicollinearity between independent variables could create the outcome (Field, 2013). To ensure there is no multicollinearity in the present data, variance inflation (VIF) and tolerance value were checked. If the value of VIF is more than 10 and the value of tolerance is less than .10, there is possible multicollinearity (Hair et al., 2014). VIF values were 2.873 for risk management, 1.957 for accountability and 3.066 for management commitment (see Table 4). Therefore, it can be concluded there is no serious multicollinearity problem among the variables. Another popular way to check multicollinearity is via HTMT ratio. Table 4 indicates that the HTMT ratio is lower than the suggested value of 0.90 (Hair et al., 2019; Henseler et al., 2015). Hence, no multicollinearity issue is evident in the variables.

\section{Structural model}

In the second step, we employed bootstrapping as suggested by Henseler et al. (2009). 


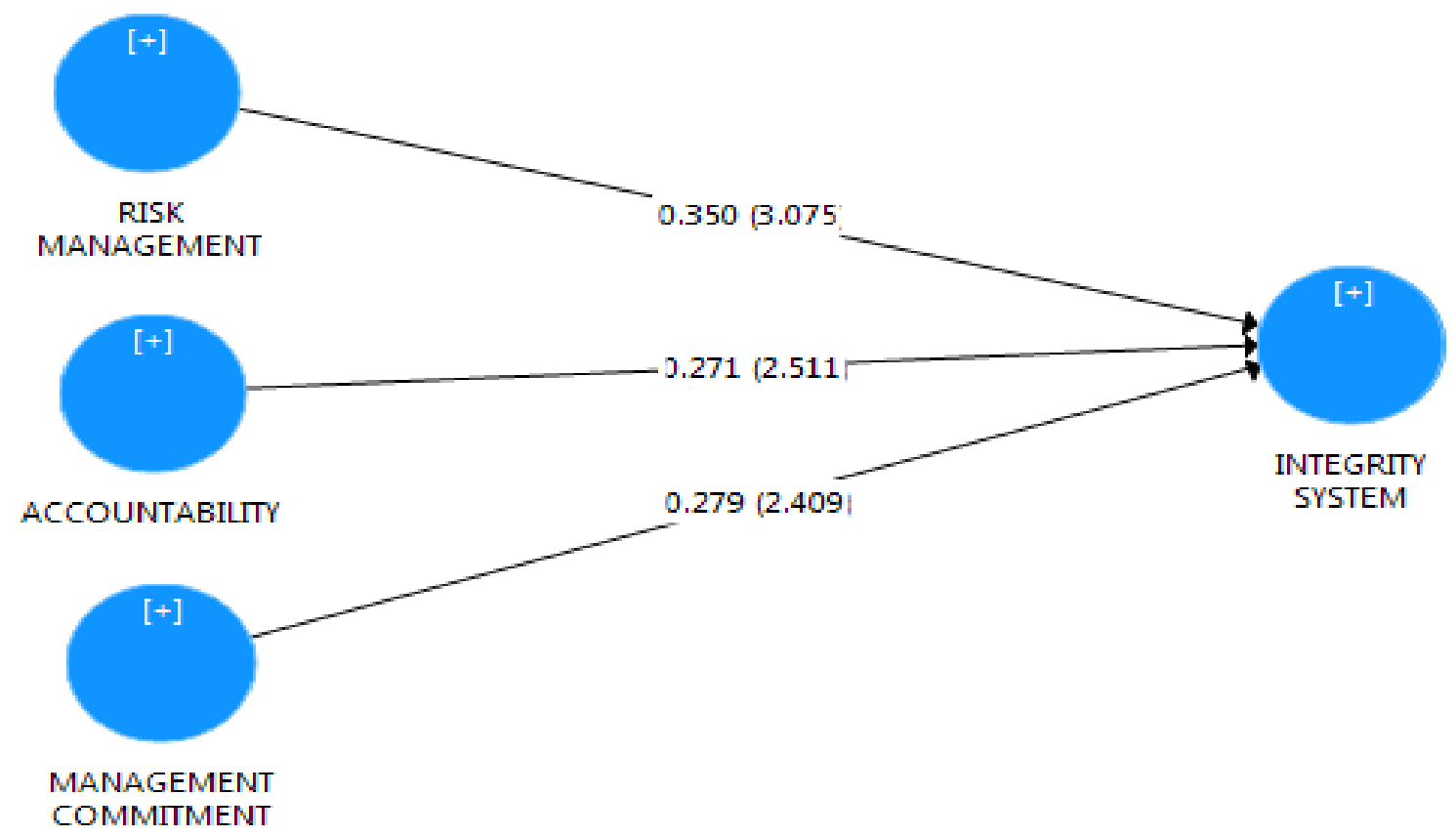

Figure 4: Structural Model

As presented in Figure 4 the coefficient of determination $\left(\mathrm{R}^{2}\right)$ is 0.653 . It means integrity practices were explained by variations in risk management, accountability and management commitment. According to Hair et al. (2019) the model has good fit and predictive power.

\section{DISCUSSION}

This study explored the relationship of three variables, namely risk management, accountability and management commitment in the public sector in enhancing integrity. Based on the 194 respondents, several analyses were carried out to test the hypotheses. The objectives of this study are to examine: (i) the relationship between risk management and integrity in the public sector; (ii) the relationship between accountability and integrity in the public sector; and (iii) the relationship between management commitment and integrity in the public sector. Based on the results of the findings, all objectives are achieved since all three hypotheses based on Stakeholder Theory were supported.

The first hypothesis sets out to assess the relationship between risk management and integrity in the public sector. According to the result, risk management shows a significantly positive relationship with integrity practice $(\beta=0.350, \mathrm{t}=3.141, \mathrm{p}<0.01)$. Hence, H1 was supported and this is backed up by Baharuddin, Shokiyah and Ibrahim (2014) who stated that corporate governance assists government departments to achieve integrity and assist stakeholders through proper risk management. This finding reveals the emphasis on controlling activities and operations through risk management which guarantees the strength of integrity in the public sector.

Currently, the Malaysian government is facing a situation where some government officers practice cronyism and this has damaged the public sector as a whole. Therefore, proper controlling by implementing a better procedure of risk management is very crucial since it can increase the confidence of stakeholders. This result echoes that of Baharud-din, Shokiyah and Ibrahim (2014) who stated that corporate governance assists public sector bodies to achieve integrity and help stakeholders through proper risk management. However, what they 
found contrasts the finding of Said et al. (2016) who asserted that risk management does not influence integrity practices.

Next, the second hypothesis observes the relationship between accountability and integrity in the public sector. Hypothesis $\mathrm{H} 2$ is supported as accountability shows a significantly positive relationship with integrity practice $(\beta=0.271, \mathrm{t}=2.546, \mathrm{p}<0.05)$. This result agrees with the research by Mintrop (2012) and Aziz et al. (2015) who discovered that integrity practice has a relationship with accountability where using integrity nurtures accountability. This finding shows that the government's effort in establishing a system with integrity has produced better accountability especially in the public sector. It can be achieved by applying a resilient integrity practice that is consistent and manageable.

Thirdly and finally, the analysis found that management commitment shows a significantly positive relationship with integrity practice $(\beta=0.279, \mathrm{t}=2.395, \mathrm{p}<0.05)$. Therefore, H3 was supported. This positive finding suggests that strong senior management commitment in responsibilities to all staff is crucial since it encourages an integrity practice environment throughout the whole department. Research by Leroy et al. (2012) echoed this finding as they found that authentic leadership is related to affective organisational commitment which is fully mediated through a leader's behavioural integrity. Rutkowski and Steelman (2005) also support the findings of this study in that the leaders who manage an organisation do influence the level of accountability and integrity practices.

\section{CONCLUSION}

The findings from this study have shown a significant effect risk management, accountability and management commitment have in shaping the integrity of the public sector. From the findings, one could conclude that it is very important for the organisation to implement or establish risk management policies, insert a high level of accountability and have a great commitment to the honesty of the public sector and in officers' daily activities. Every department in the ministry should publish a public report on the ethics and integrity activities done to develop good governance practices and societal outcomes.

In addition, the findings add support to stakeholder theory. The public sector protects the stakeholders' interests by ensuring people are treated equally and not showing favouritism in order to achieve policy outcomes. Since the government is developing Malaysia as a modern nation, the function of the departmental head especially in matters of integrity and ethicality is really important in order to accomplish the Government Transformation Programme (GTP) and Economic Transformation Programme (ETP). This study has been conducted with some limitations that could be improved in future studies. The first limitation concerns the variables that were chosen in this study as they are only able to explore some factors, namely risk management, accountability and management commitment in assessing their relationships with integrity in a public sector environment. In such an environment, there are many other factors that might influence integrity in the public sector such as internal control system, ethics, organisational effectiveness, quality of leadership and others. These factors could be explored in more detail in future research.

The second limitation concerns the sample chosen since this study used six (6) ministries in Malaysia and they were selected based on the Auditor General's report for the last three years. In reality there are 24 ministries in the Malaysian public sector. Therefore, the sample of the study might not be enough to obtain accurate results. Future studies might use a larger 
sample so that the information and results will be more accurate and represent the updated opinions of all departments in the Malaysian public sector.

Lastly, this paper only focuses on the opinions offered by the Head of Department (HOD) and did not take into account the opinions of lower level officers. In order to obtain opinions from all public servants so that the information is accurate and balanced, future researchers are advised to compare and contrast officers' different opinions about integrity in the public sector. Finally, future studies might also include perspectives from academic institutions and their role in cultivating integrity practices in present and future public sector officers.

\section{REFERENCES}

Abdullah, M., Shukor, Z. A., Mohamed, Z. M. and Ahmad, A. (2015), "Risk management disclosure", Journal of Applied Accounting Research, 16(3), pp. 400-432.

Aladwan, K., Bhanugopan, R. and Fish, A. (2013), "To what extent the Arab workers commited to their organisations? Analysing the multidimensional prspective of organisational commitment in Jordan", International Journal of Commerce and Management, 23(4), pp. 306-326.

Alam, M.M., Johari, R.J. \& Said, J. (2018), “An Empirical Assessment of Employee Integrity in the Public Sector of Malaysia", International Journal of Ethics and Systems, 34(4), 458-471.

Almquist, R., Grossi, G., Helden, G. J. v. and Reichard, C. (2013), "Public sector governance and accountability", Critical Perspectives on Accounting, 24(7-8), pp. 479-487.

Archbold, C. A. (2005), "Managing the bottom line: risk management in policing", Policing: An International Journal of Police Strategies and Managment, 28(1), pp. 30-48.

Arulrajah, A.A., Opatha, H.H.D.N.P. and Nawaratne, N.N.J. (2016), "Green human resource management practices: a review", Sri Lankan Journal of Human Resource Management, 5(1), pp.1-16. DOI: http://doi.org/10.4038/sljhrm.v5i1.5624

Asaolu, T.O., Adedokun, S.A., \& Monday, J.U. (2016), "Promoting Good Governance through Internal Audit Function (IAF): The Nigerian Experience", International Business Research, 9, 196-204.

Auditor General Report. (2013). Jabatan Audit Negara, Kerajaan Malaysia.

Aulich, C. (2011), "Integrity Agencies as One Pillar of Integrity and Good Governance. Public Policy and Administration, 10(1), pp. 41-52. http://dx.doi.org/10.5755/j01.ppaa.10.1.227

Aziz, M. A. A., Rahman, H. A., Alam, M. M. and Said, J. (2015), "Enhancement of the Accountability of Public Sectors through Integrity System, Internal Control System and Leadership Practices: A Review Study", Procedia Economics and Finance, 28, pp. 163-169.

Badaracco, J. L. and Ellsworth, R. R. (1991), "Leadership, Integrity and Conflict", Journal of Organizational Change Management, 4(4), pp. 46-55.

Baharud-din, Z., Shokiyah, A. and Ibrahim, M. S. (2014), "Factors that Contribute to the Effectiveness of Internal Audit in Public Sector", 70(24), pp. 126-132. doi: 10.7763/IPEDR.2014.V70.24

Bauman, D. C. (2013), "Leadership and the three faces of integrity", The Leadership Quarterly, 24, pp. 414-426.

BERNAMA. (2016b), Bekas Penolong Pengarah Didakwa Rasuah, Lulus Pesanan Kerajaan RM45,572. Mstar.Com.My. Retrieved from http://www.mstar.com.my/berita/beritamahkamah/2016/08/15/penolong-pengarah-rasuah/. 
Bovens, M., R. E. Goodin \& T. Schillemans (Eds.) (2014), The Oxford Handbook of Public Accountability. Oxford: Oxford University Press.

Brennan, N.M. \& Solomon, J. (2008), "Corporate Governance, Accountability and Mechanisms of Accountability: An Overview", Accounting, Auditing \& Accountability Journal, 21, pp. 885-906

Bribe Payers Index. (2011), "Transparency International: the global coalition against corruption". Retrieved from https://www.transparency.org/en/press\#

Buysse, K. \& Verbeke, A. (2003), "Proactive environmental strategies: a stakeholder a stakeholder management perspective”, Strategic Management Journal, 24(5), pp. 453470.

Chabrak, N. (2015), "Promoting corporate social responsibility and sustainability: a model of integrity", Society and Business Review, 10 (3), pp. 280-305.

Chan, J. (2016), "MACC arrests of Sabah officers give way to biggest seizure haul in history", Malay Mail Online, p. 1. Retrieved from http://www.themalaymailonline.com/malaysia/article/macc-arrests-of-sabah-officersgive-way-to-biggest-seizure-haul-in-history\#sthash.lGy591mR.dpuf.

Collier, P. M. (2008), "Stakeholder accountability: A field study of the implementation of a governance improvement plan", Accounting, Auditing and Accountability Journal, 21(7), pp. 933-954.

Cressey, D. R. (1973), Other People's Money: A study of the social psychology of embezzlement. Retrieved from http://www.worldcat.org/title/other-peoples-money-astudy-in-the-social-psychology-of-embezzlement/oclc/628437.

Damak-Ayadi, S. and Pesqueux, Y. (2005), "Stakeholder theory in perspective", Corporate Governance, 5(2), pp. 5-21.

Doh, J.P. and Stumpf, S.A. (2005), "Towards a Framework of Responsible Leadership and Governance". In: Doh, J.P. and Stumpf, S.A., Eds., Handbook on Responsible Leadership and Governance in Global Business, Edward Elgar, Cheltenham, 3-18. http://dx.doi.org/10.4337/9781845425562.00007

Donaldson, T. \& Dunfee, T.W. (1999), Ties that Bind: A Social Contracts Approach to Business Ethics. Harvard Business School Press.

Dooren, W. V., Bouckaert, G. and Halligan, J. (2015), Performance Management in the Public Sector, $2^{\text {nd }}$ ed. London: Routledge.

Dorminey, J., Fleming, A. S., Kranacher, M. J., and Riley Jr, R. A. (2012). "The evolution of fraud theory", Issues in Accounting Education, 27(2), pp.555-579.

Engelbrecht, A. S., Heine. G, and Mahembe, B. (2017), "Integrity, ethical leadership, trust and work engagement", Leadership \& Organization Development Journal, 38(3), pp. 368-379.

Fadzil, Firdaous (2016), "DBKL executive director faces 18 charges involving RM4.4m", The Star Online. Retrieved from http://www.thestar.com.my/news/nation/2016/09/09/kl-city-hall-executive-directorfaces-18-corruption-charges/.

Field, A. (2013), Discovering Statistics Using IBM SPSS Statistics, $4^{\text {th }}$ ed. New Jersey: SAGE Publications.

Francés-Gómez, P. (2003), "Some Difficulties in Sacconi's View about Corporate Ethics", Journal of Business Ethics, 42(2), pp. 165-180.

Freeman, R. E. (1984), Strategic management: A stakeholder perspective. Boston: Pitman.

Geer, B. W. (2009), Nonprofit Accountability: An institutional and resource dependence lens on conformance and resistance. (Doctor of Philosophy), University of Pittsburgh. 
Gigerenzer, G., \& Hug, K. (1992), "Domain-specific reasoning: Social contracts, cheating, and perspective change", Cognition, 43(2), pp. 127-171. https://doi.org/10.1016/00100277(92)90060-U

Glynn, J. J. and Murphy, M. P. (1996), "Public Management: Failing accountabilities nd failing performance review", International Journal of Public Sector Management, 9(5/6), pp. 125-137.

Goffin, K. and Szwejczewski, M. (1996), "Is management commitment to quality just a given?", The TQM Magazine, 8(2), pp. 26-31.

Gollmar, W. G. (2008), Capacity Building and Nonprofit Organizational Effectiveness, Cardinal Stritch University.

Graaf, G. de, Huberts, L., \& Strüwer, T. (2017), "Integrity Violations and Corruption in Western Public Governance: Empirical Evidence and Reflection from the Netherlands", Public Integrity, O(0), 1-19. https://doi.org/10.1080/10999922.2017.1350796

Hair, J. F., Black, W. C., Babin, B. J., \& Anderson, R. E. (2014), Multivariate Data Analysis: Pearson New International Edition, $7^{\text {th }}$ ed. New York: Pearson Higher Education.

Hair, J. F., Risher, J. J., Sarstedt, M., \& Ringle, C. M. (2019), "When to use and how to report the results of PLS-SEM", European Business Review, 31(1), pp. 2-24.

Hall, A. T., Blass, F. R., Ferris, G. R. and Massengale, R. (2004), "Leader reputation and accountability in organizations: Implication for dysfunctional leader behavior", The Leadership Quarterly, 15(4), pp. 515-536.

Harian, Sinar (2017), Rasuah: Dua penjawat awam pula direman. Sinar-Harian. Retrieved from http://www.sinarharian.com.my/semasa/rasuah-dua-penjawat-awam-puladireman-1.625512.

Henseler, J., Ringle, C. M., \& Sarstedt, M. (2015), "A new criterion for assessing discriminant validity in variance-based structural equation modeling", Journal of the Academy of Marketing Science, 43(1), pp. 115-135.

Henseler, J., Ringle, C. M., \& Sinkovics, R. R. (2009), “The use of partial least squares path modeling in international marketing. Advances in International Marketing, 20, pp. 277319.

Hopkin, M. R. (2012), "Leadership and Integrity". Retrieved October 24, 2016, from https://www.researchgate.net/deref/http $\% 3 \mathrm{~A} \% 2 \mathrm{~F} \% 2 \mathrm{Fleadonpurposeblog.com} \% 2 \mathrm{~F} 2012$ $\% 2 \mathrm{~F} 01 \% 2 \mathrm{~F} 21 \% 2 \mathrm{Fleadership}$-and-integrity\%2F.

Hopkins, M. M., O'Neil, D. A. and Williams, H. W. (2007), "Emotional intelligence and board governance: Leadership lessons from the public sector", Journal of Managerial Psychology, 22(7), pp. 683-700.

Huse, M. (2005), “Accountability and Creating Accountability: a Framework for Exploring Behavioural Perspectives of Corporate Governance", British Journal of Management, 16, S65-S79.

Iyoha, F. O. and Oyerinde, D. (2010), "Accounting insfrastructure and accountability in the management of public expenditure in developing countries: A focus on Nigeria", Critical Perspectives on Accounting, 21, pp. 361-373.

Jamaludin, S. N. (2018), Rasuah RM4 juta, Pengarah JPS Perlis, 2 Kontraktor direman. Utusan Malaysia, p. $1 . \quad$ Retrieved from http://www.utusan.com.my/berita/mahkamah/rasuah-rm4-juta-pengarah-jps-perlis-2kontraktor-direman-1.600012.

Jayasinghe, K. and Soobaroyen, T. (2009), "Religious spirit and people's perceptions of accountability in Hindu and Buddhist religious organizations", Accounting, Auditing and Accountability Journal, 22(7), pp. 997-1028.

Jensen, M. C. (2001), "Value Maximization, Stakeholder Theory, and the Corporate Objective Function", Journal of Applied Corporate Finance, 14(3), pp. 8-21. 
Johari, R. J., Alam, M. M., \& Said, J. (2018), “Assessment of Management Commitment in Malaysian Public Sector”, Cogent Business \& Management, 5, p. 1469955.

Johari, R. J., Ida Rosnidah, Ahmad Nasfy, S. S. \& Sayed Hussin, S. A. H. (2020), "The effects of ethical orientation, individual culture and ethical climate on ethical judgement of public sector employees in Malaysia", Economics and Sociology, 13(1), pp. 132-145.

Kalsi, N. S., Kiran, R. and Vaidya, S. C. (2009), "Changing perspectives and pragmatics of good governance and e-governance in India: A shared vision of citizens", International Journal of Electronic Governance, 2(2-3), pp. 251-271.

Kaptein, M. (2003), "The diamond of managerial integrity", European Management Journal, 21(1), pp. 99-108.

Khalid, M. A., Alam, Md. M., Said, J. (2016), "Empirical Assessment of Good Governance in the Public Sector of Malaysia", Economics and Sociology, 9(4), pp. 289-304.

Kolthoff, E. (2016), "Integrity Violations, White-Collar Crime, and Violations of Human Rights: Revealing the Connection", Public Integrity, 18(4), pp. 396-418. https://doi.org/10.1080/10999922.2016.1172933

KPMG Integrity Survey. (2013), KPMG Forensic: Cutting through complexity. Retrieved from https://assets.kpmg/content/dam/kpmg/pdf/2013/08/Integrity-Survey-2013-O201307.pdf

Leroy, H., Palanski, M. E. and Simons, T. L. (2012), "Authentic Leadership and Behavioral Integrity as Drivers of Follower Commitment and Performance", Journal of Business Ethics, 3, pp. 255-264.

Loewenthal, K. M. (2004), An introduction to psychological tests and scales, $2^{\text {nd }}$ ed. Hove, UK: Psychology Press.

Ma, F. (2016), "Business integrity v. business efficiency: the corporate opportunity doctrine in China", Journal of Financial Crime, 23(1), pp. 201-215.

MACC. (2017a), Pasangan Suami Isteri Pegawai Tldm Disiasat Sprm, Dihukum Penjara. Retrieved from https://docs.google.com/gview?embedded=true\&url=http://www.sprm.gov.my/images/ PASANGANSUAMI_ISTERIPEGAWAITLDMDISIASATSPRMDIHUKMPENJAR A.pdf.

MACC. (2017b), Penolong Pegawai Pejabat Tanah Dituduh Terima Suapan RM150,000. Retrieved from http://www.sprm.gov.my/images/Kenyataan_Media/PEGAWAIPEJABAT_TANAHD AERAHJBDITUDUHTERIMASUAPAN.pdf.

Malaysian Integrity System (2012), A Consultative Document on Corporate Integrity System Assessment Questionnaire: Corporate Integrity System Malaysia 2010-2012, Institut Integriti Malaysia.

Mancuso, M. (2012), "Nonprofit Risk Management", The Philanthropist, 24(3).

Metcalfe, B. and Dick, G. (2001), "Exploring organisation commitment in the police implications for human resource strategy", Policing: An International Journal of Police Strategies and Management, 24 (3), pp. 399-419.

Millar, P. and Doherty, M. (2016), "Capacity building in nonprofit sport organizations: Development of a process model”, Sport Management Review, 19(4), pp. 365-377.

Mintrop, H. (2012), "Bridging accountability obligations, professional values and (perceived) student needs with integrity", Journal of Educational Administration, 50(5), pp. 695726.

Miwil, O. (2018), "Bank Accounts Frozen, Properties Seized in JKNS Corruption Probe", New Straits Times Online, p. 1. Retrieved from https://www.nst.com.my/news/crimecourts/2018/01/328555/bank-accounts-frozen-properties-seized-jkns-corruption-probe. 
Mowday, R. T., Steers, R. M. and Porter, L. W. (1979), "The measurement of organizational commitment", Journal of Vocational Behavior, 14(2), pp. 224-247.

Ng, T.-H., Chong, L.-L. and Ismail, H. (2013), "Is the risk management committee only a procedural compliance?", The Journal of Risk Finance, 14(1), pp. 71-86.

Nunnally, J. C. (1978), Psychometric theory, $2^{\text {nd }}$ ed. New York: McGraw-Hill.

Pallant, J. (2005), SPSS Survival Manual: A Step by Step Guide to Data Analysis Using SPSS for Windows, $3^{\text {rd }}$ ed. New York: Open University Press.

Rasid, S. Z. A., Rahman, A. R. A. and Ismail, W. K. W. (2011), "Management accounting and risk management in Malaysian financial institutions", Managerial Auditing Journal, 26(7), pp. 566-585.

Riege, A. and Lindsay, N. (2006), "Knowledge management in the public sector: stakeholder partnerships in the public policy development", Journal of Knowledge Management, 10(3), pp. 24-39.

Rutkowski, K. A. and Steelman, L. A. (2005), "Testing a path model for antecedents of accountability", Journal of Management Development, 24(5), pp. 473-486.

Sacconi, L. (1999), "Codes of Ethics as Contractarian Constraints on the Abuse of Authority within Hierarchies: A Perspective from the Theory of the Firm", Journal of Business Ethics, 21(2), pp. 189-202. https://doi.org/10.1023/A:100620271148.

Said, J., Alam, M. M. and Khalid, M. A. (2016), "Relationship between good governance and integrity system: Empirical study on the public sector of Malaysia", Humanomics, 32(2), pp. 151-171.

Shaoul, J., Stafford, A. and Stapleton, P. (2012), "Accountability and corporate governance of public private partnerships", Critical Perspectives on Accounting, 23(3), pp. 213229.

Siddiquee, N. A. (2006), "Public management reform in Malaysia: Recent initiatives and experiences", International Journal of Public Sector Management, 19(4), pp. 339-358.

Smallman, C. (1996), "Risk and organizational behaviour: A research model", Disaster Prevention and Management: An International Journal, 5(2), pp. 12-26.

Ssonko, D. K. W. (2010), "Ethics, Accountability, Transparency, Integrity and Professionalism in the Public Service: The Case of Uganda". Working papers, presented at Capacity Building Workshop for Public Sector Human Resource Managers in Africa on "Strengthening Human Resource Capacities for the Achievement of the Millennium Development Goals and Africa's Development," 12-16 April, 2010.

Subramaniam, N., McManus, L., Zhang, J. (2009), "Corporate governance, firm characteristics and risk management committee formation in Australian companies", Managerial Auditing Journal, 24, pp. 316-339.

Suyono, E. \& Hariyanto, E. (2012), "Relationship Between Internal Control, Internal Audit, And Organization Commitment With Good Governance Indonesian Case", China-USA Business Review, 11(9), 1237-1245. Retrieved from http://dx.doi.org/10.17265/15371514/2012.09.006

Tabachnick, B. G., and Fidell, L. S. (2001), Using multivariate statistics, $4^{\text {th }}$ ed. New York: Allyn and Bacon.

Tchankova, L. (2002), "Risk identification-basic stage in risk management", Environmental Management and Health, 13(3), pp. 290-297.

The Star. (3 December 2014), Malaysia climbs up three places in Corrupion Index. Kuala Lumpur, Malaysia: The Star Publication.

The Star. (30 September 2015), Keeping the fight against corruption alive. Kuala Lumpur, Malaysia: The Star Publication. 
Trevinyo-Rodriguez, R. N. (2007), "Integrity: A system theory classification", Journal of Management History, 13(1), pp. 74-93.

Tummala, R. and Achoenherr, T. (2011), "Assessing and managing risks using the Supply Chain Risk Management Process (SCRMP)", Supply Chain Management: An International Journal, 16(6), pp. 474-483.

Williams, S. J. and Adams, C. A. (2013), "Moral accounting? Employee disclosures from a stakeholder accountability perspective", Accounting, Auditing and Accountability Journal, 26(3), pp. 449-495.

Wilson, F. M. (2018), Organizational Behaviour and Work: A Critical Introduction, $5^{\text {th }}$ ed. United Kingdom: Oxford University Press.

Wombacher J. C. and Felfe, J. (2017), "Dual commitment in the organization: Effects of the interplay of team and organizational commitment on employee citizenship behavior, efficacy beliefs, and turnover intentions", Journal of Vocational Behavior, 102, pp. 114. 